\title{
Interactions between the toxic estuarine dinoflagellate Pfiesteria piscicida and two species of bivalve molluscs
}

\author{
Jeffrey J. Springer ${ }^{1, *}$, Sandra E. Shumway ${ }^{2}$, JoAnn M. Burkholder ${ }^{1}$, Howard B. Glasgow ${ }^{1}$ \\ ${ }^{1}$ Center for Applied Aquatic Ecology, North Carolina State University, 620 Hutton Street, Suite 104, Raleigh, \\ North Carolina 27606, USA \\ ${ }^{2}$ Department of Marine Sciences, University of Connecticut, 1080 Shennecossett Road, Groton, Connecticut 06340, USA
}

\begin{abstract}
Toxic strains of Pfiesteria spp. produce toxin(s) that can cause finfish death, but much less is known about impacts of Pfiesteria on shellfish. Here we conducted 4 experiments to examine interactions between shellfish and toxic (actively toxic or TOX-A from finfish-killing cultures and potentially toxic or TOX-B from cultures without finfish) and non-inducible (NON-IND, apparently incapable of killing fish via a toxic effect) strains of P. piscicida. First (Expt 1), we documented direct physical attack by P. piscicida TOX-A, TOX-B, and NON-IND zoospores on larvae of the bay scallop Argopecten irradians (Lamarck, 1819) and the eastern oyster Crassostrea virginica (Gmelin, 1791). Within 5 min zoospores swarmed around larvae that had discarded their vela, and attached with their peduncles. Within $15 \mathrm{~min}$ they had penetrated into the shellfish visceral cavity and had begun to feed aggressively; after 30 min all shellfish tissues except the adductor muscle had been consumed. Second, we tested the response of scallop larvae to P. piscicida (TOX-A or TOX-B) or cryptomonads (as controls) that were held in dialysis tubing $(0.22 \mu \mathrm{m}$ porosity) to prevent direct contact. After $60 \mathrm{~min}$ larval survival was $0 \%$ in the TOX-A treatment, $100 \%$ in the cryptomonad control, and intermediate in TOX-B and TOX-B + cryptomonad treatments. The data indicate a toxic effect of $P$. piscicida zoospores on the larvae, separate from the physical effect shown in Expt 1. Third, we compared grazing by juvenile and adult oysters on TOX-A, TOX-B, and NON-IND P. piscicida zoospores from the medium. After $60 \mathrm{~min}$, grazing by juvenile oysters significantly differed as NON-IND $\gg$ TOX-B $\gg$ TOX-A. In contrast, adult oysters grazed significantly fewer TOX-A zoospores and maintained comparable grazing on TOX-B and NON-IND zoospores. Thus juvenile oysters, but not adults, were sensitive to residual toxicity of TOX-B zoospores, and both life-history stages were sensitive to TOX-A zoospores. The adverse effects of toxic strains on larval survival and juvenile grazing indicate that $P$. piscicida could potentially affect shellfish recruitment. Fourth, we assessed zoospore survival after passage through the digestive tract of adult oysters. The feces contained many temporary cysts from zoospores, and within $24 \mathrm{~h}>75 \%$ of the cysts produced motile cells. The data indicate that adult oysters would be poor biocontrol agents of $P$. piscicida, given the high survival of ingested zoospores following gut passage and fecal elimination; and that oysters could act as vectors of toxic $P$. piscicida strains if transported from affected estuaries to other waters.
\end{abstract}

KEY WORDS: Argopecten irradians · Crassostrea virginica · Oyster · Pfiesteria · Scallop · Shellfish · Temporary cyst $\cdot$ Toxic dinoflagellate

Resale or republication not permitted without written consent of the publisher

\section{INTRODUCTION}

Toxic dinoflagellates include species that, when accumulated by shellfish consumed as seafood, can lead to illness and death of humans (Shumway 1990, Bricelj \& Shumway 1998, Burkholder 1998, Matsuyama et al. 1999). Although shellfish had been regarded as unaffected vectors of these toxins, it is now known that 
toxic dinoflagellates can significantly affect the survival and physiology of bivalve molluscs, including species-specific changes in feeding, respiration, shell valve closure, mucus production, and cardiac activity (Shumway et al. 1985, 1987, Shumway \& Cucci 1987, Gainey \& Shumway 1988a,b, Shumway 1990, 1995, Matsuyama et al. 1999).

Among the more recently known toxic dinoflagellate species is Pfiesteria piscicida Steidinger \& Burkholder, which was first detected in the early 1990s as an ichthyotoxic organism in the Albemarle-Pamlico Estuarine System of the southeastern US (Burkholder et al. 1992, 2001a). Toxic Pfiesteria spp. outbreaks have been linked to the death of $>1$ billion fish in that system, which is the second largest estuary on the US mainland (Burkholder \& Glasgow 1997, Burkholder et al. 1999, Glasgow et al. 2001a). Several small outbreaks also have occurred in the largest US mainland estuary, Chesapeake Bay (Magnien et al. 2000, Magnien 2001), and toxic Pfiesteria spp. strains have been documented from other geographic regions as well (Jakobsen et al. 2002, Rhodes et al. 2002). Toxicity in Pfiesteria spp. is activated by substances in fresh finfish tissues, excreta and secreta (Burkholder et al. 1992, 2001a, Marshall et al. 2000). Like other toxic algae (Gentien \& Arzul 1990, Anderson 1991, Skulberg et al. 1993, Bates et al. 1998, Edvardsen \& Paasche 1998), Pfiesteria spp. include both toxic and 'benign' strains (the latter, non-inducible or apparently incapable of causing fish death with toxin as live cells: Burkholder et al. 2001a). Also like other toxic algae, many toxic strains of Pfiesteria spp. have lost toxicity over time in culture, possibly because required organic substrates and/or bacterial cofactors from the natural environment are lacking (Burkholder et al. 2001a). A potent water-soluble toxin has been purified from Pfiesteria spp. (Drs. J. Ramsdell \& P. D. R. Moeller, National Ocean Service, Charleston, South Carolina, USA, pers. comm.), and fish-killing and pharmacological activity demonstrated (Kimm-Brinson et al. 2001, Melo et al. 2001) but, as for other toxic dinoflagellates, the factors controlling toxin production are poorly understood.

The available data indicate that toxicity status in Pfiesteria spp. zoospores includes 3 'functional types'. Toxic strains may be either actively toxic (TOX-A, in the presence of live fish under conductive culture conditions: Burkholder et al. 2001b) or temporarily nontoxic (TOX-B, without live fish, sometimes retaining residual toxicity and capable of becoming TOX-A when live fish become available [Burkholder et al. 2001c], sometimes referred to as nontoxic [e.g. Burkholder \& Glasgow 1997]). Non-inducible (NON-IND) strains, in contrast, are incapable of causing fish death as a toxin effect as mentioned, based on the present understanding of these organisms (Burkholder et al. 2001b). The 3 functional types of $P$. piscicida have shown distinct behaviors in response to nutrients (Burkholder et al. 2001b), algal prey (Parrow et al. 2002), microfaunal grazers (Stoecker et al. 2002), and finfish (Burkholder et al. 2001a, Cancellieri et al. 2001). Toxic Pfiesteria spp. strains have caused death in some shellfish species (Burkholder \& Glasgow 1997), but the response of shellfish to toxic versus non-inducible Pfiesteria strains has not been tested. The objectives of this study were to examine interactions between toxic (TOX-A, TOX-B) and NON-IND strains of $P$. piscicida and 2 commercially and ecologically important shellfish species, the bay scallop Argopecten irradians (Lamarck, 1819) and the eastern oyster Crassostrea virginica (Gmelin, 1791).

\section{MATERIALS AND METHODS}

Pfiesteria piscicida cultures. Using a standardized fish bioassay procedure (Burkholder \& Glasgow 1997, Burkholder et al. 2001c), we isolated a toxic clone of $P$. piscicida (defined as in the Pfiesteria Interagency Coordination Working Group: PICWG 2002) from the mesohaline Neuse Estuary near Minnesott Beach, North Carolina, USA, a tributary of the AlbemarlePamlico (Glasgow \& Burkholder 2000). The clone (Center for Applied Aquatic Ecology [CAAE] NE121, zoospore diameter 6 to $8 \mu \mathrm{m}$ ) was obtained following flow cytometric procedures described by Glasgow et al. (2001b), using a COULTER ${ }^{\circledR}$ EPICS $^{\circledR}$ ALTRA $^{\text {TM }}$ flow cytometer with HyPerSort ${ }^{\mathrm{TM}}$ System (Coulter), equipped with a water-cooled INNOVA ${ }^{\mathrm{TM}}$ Enterprise II $^{\mathrm{TM}}$ Ion Laser (Coherent). P. piscicida was identified from suture-swollen zoospores using scanning electron microscopy (SEM; procedure of Burkholder \& Glasgow 1995, Glasgow et al. 2001b), additionally checked with a species-specific polymerase chain reaction (PCR) probe (Rublee et al. 1999, 2001). The identification was crosscorroborated by Dr. P. Rublee (PCR: University of North Carolina-Greensboro, Greensboro, North Carolina, USA), and by Dr. H. Marshall (SEM: Old Dominion University, Norfolk, Virginia, USA; Marshall et al. 2000).

All cultures were maintained at $21^{\circ} \mathrm{C}$ and $100 \mu \mathrm{mol}$ photons $\mathrm{m}^{-2} \mathrm{~s}^{-1}$ at a 14:10 h light:dark ratio. An actively toxic (TOX-A) sub-culture from this clonal culture was maintained with live fish in ultra-filtered $(0.2 \mu \mathrm{m}$ porosity Versapor filtration capsules, Pall Gelman Corporation) natural seawater that had been collected ca. $40 \mathrm{~km}$ off Cape Hatteras, North Carolina, USA; salinity was adjusted to 15 or $25 \mathrm{ppt}$ using sterile-filtered Millipore $\mathrm{Q}$ water). The TOX-A sub-culture was maintained in a biohazard III containment system that was specially designed to ensure safe conditions when working with toxic Pfiesteria species (required by the 
Department of Environmental Health and Safety, North Carolina State University [NCSU], Raleigh, North Carolina, USA; Burkholder et al. 2001c). A TOX-B subculture from the actively toxic clonal culture was grown with clonal cryptomonad algal prey (Cryptomonas sp. HP9101; source, Dr. A. Lewitus, University of South Carolina, Charleston, South Carolina, USA) for 6 wk prior to the experiments (TOX-B zoospore diameter 6 to $8 \mu \mathrm{m})$. The cryptomonad culture was maintained at $10^{4}$ cells $\mathrm{ml}^{-1}$, and grown in $\mathrm{f} / 2-\mathrm{Si}$ media (Guillard 1975) made with sterile-filtered natural seawater (salinity 15 or 25 ppt). The TOX-B subculture was retested $6 \mathrm{wk}$ before the experiments in fish bioassays to confirm toxicity. A second clonal $P$. piscicida culture (CAAE \#98B) was, of necessity, needed for NON-IND zoospores. The clone had been isolated as a toxic strain from the mesohaline Neuse ca. 6 mo earlier, but had become non-inducible over time in culture. The NON-IND strain (zoospore diameter 6 to $7 \mu \mathrm{m}$ ) had also been maintained on cryptomonad prey, and was acclimated to a salinity of 15 or 25 ppt for the experiments.

Shellfish. All shellfish were obtained from Dr. G. Wikfors (National Marine Fisheries Service [NMFS], Milford, Connecticut, USA). Shellfish reared in waters from New York, USA southward (known northernmost extension of Pfiesteria piscicida distribution: Allen 2000) were not used to minimize the potential for prior exposure to Pfiesteria spp. zoospores or contamination with cysts. Water samples collected adjacent to NMFSMilford were examined with light microscopy to check for the presence of pfiesteria-like zoospores, and with PCR probes to test for P. piscicida and P. shumwayae Glasgow \& Burkholder (Rublee et al. 1999, 2001, Allen 2000, Oldach et al. 2000), the 2 known toxic Pfiesteria spp. (Burkholder et al. 2001a, Glasgow et al. 2001b). Pfiesteria spp. were not detected.

The larval bay scallops and eastern oysters had been spawned at the salinities required for experimentation (25 and 15 ppt, respectively), and had been maintained on a mixed algal diet (primarily Isochrysis cf. galbana or Rhodomonas sp. [20 ${ }^{\circ} \mathrm{C}$ ] prior to shipment. Juvenile and adult oysters (mean shell height 22.3 and $64.2 \mathrm{~mm}$, respectively) were obtained from NMFS-Milford and transferred to separate (15 or 25 ppt) 9501 recirculating seawater systems at $21^{\circ} \mathrm{C}$. The shellfish were allowed to acclimate for $\geq 2 \mathrm{~d}$ to clear previously consumed algal prey from their digestive system. Shellfish were gently brushed $24 \mathrm{~h}$ before each experiment to remove epibionts, and were held in a tank equipped with ultraviolet sterilization. These steps were taken to minimize transfer of microbial contaminants into experimental treatments.

Sampling design and analyses. Four experiments were carried out as follows:
Expt 1-Pfiesteria piscicida predation on larval shellfish: The 2 shellfish species were maintained separately, and 100 larvae (mean length $61 \mu \mathrm{m}$ ) of each species were exposed to a standardized density of $5 \times$ $10^{3}$ cells $\mathrm{ml}^{-1}$ in each treatment $(\mathrm{n}=3)$. Treatments consisted of larvae exposed to TOX-A, TOX-B, and NON-IND P. piscicida zoospores; and to Cryptomonas sp. cells (controls) in ultra-filtered natural seawater (0.2 $\mu \mathrm{m}$-porosity filters; salinity 15 or $25 \mathrm{ppt}$ ). Behavioral interactions between the shellfish larvae and $P$. piscicida zoospores were observed over $24 \mathrm{~h}$. Time zero $\left(t_{0}\right)$ was recorded when zoospores were added to an optical-grade glass-bottomed petri dish with larvae. Petri dishes containing the larvae and zoospores were viewed under Nomarski optics (Olympus AX-70 research microscope, Olympus Corporation) using achromatic water immersion (Teflon-coated) lenses $(20 \times, 40 \times$, and $60 \times)$. All observations were archived on videotape (S-VHS) using a Sony SVO-9500MD video recorder. Still images were captured and digitized $(1280 \times 1024$ pixel resolution $)$ using a cooled-chip CCD camera (DEI-750D, Optronics Corporation).

Expt 2-zoospore toxicity to scallop larvae: The ability of toxic strains of Pfiesteria piscicida zoospores to induce mortality was determined by exposing 100 bay scallop larvae (in $90 \mathrm{~mm}$ petri dishes) to sterilefiltered seawater (salinity $25 \mathrm{ppt}$ ) containing $P$. piscicida and/or benign algal prey held within cellulose dialysis tubing (molecular weight cut-off of 12000 to 14000 Da, Fisher Scientific) to prevent direct contact. Treatments included TOX-A zoospores, TOX-B zoospores, Cryptomonas sp. (controls; benign algal prey as above), and a 50:50 mix of TOX-A zoospores + Cryptomonas sp. $(\mathrm{n}=3)$. Observed mortality was considered to have occurred because of the presence of $P$. piscicida toxin (defined as in PICWG 2002, Burkholder \& Glasgow 2001, Kimm-Brinson et al. 2001, Melo et al. 2001) that had diffused through the tubing. Mortality was defined as absence of ciliary movement for $>1 \mathrm{~min}$, quantified at $15 \mathrm{~min}$ intervals for $1 \mathrm{~h}$.

Expt 3-grazing by juvenile and adult oysters on Pfiesteria piscicida: Grazing trials were conducted with juvenile and adult eastern oysters (tested separately), using $P$. piscicida zoospores (TOX-A, TOX-B, or NONIND) or cryptomonads (controls) at $2.5 \times 10^{3} \mathrm{cells} \mathrm{ml}^{-1}$ for juveniles (in gently aerated $400 \mathrm{ml}$ glass beakers), and $5.0 \times 10^{3}$ cells $\mathrm{ml}^{-1}$ for adults (in aerated $2 \mathrm{lglass}$ beakers). Zoospore sub-cultures were adjusted to the desired density using ultra-filtered seawater $(0.2 \mu \mathrm{m}$ porosity; this experiment was not conducted at salinity 25 ppt because of difficulty in maintaining this strain of TOX-A zoospores over time at that salinity, but see Burkholder et al. 1995). The gentle aeration was sufficient to maintain $P$. piscicida or cryptomonad cells in suspension. Unpreserved and acidic Lugol-preserved 
samples (Vollenweider et al. 1974) of fecal material and plankton were taken at $t_{0}$ and at 15 min intervals for the first hour. Additional fecal samples were taken at $24 \mathrm{~h}$.

Zoospores were quantified using an Olympus AX-70 light microscope (Nomarski, 600×) and the Utermöhl technique (Lund et al. 1958). Cells were quantified from 20 fields selected at random down a central transect of the Utermöhl chamber (reported as cells $\mathrm{ml}^{-1}$ ), and were corroborated using a Coulter Multisizer IIe particle analyzer equipped with a $100 \mu \mathrm{m}$ aperture tube calibrated using $20 \mu \mathrm{m}$ polystyrene latex beads (L20 size standard; Coulter). Each treatment was analyzed with $20 \%$ replication (variation $<5 \%$ among replicates; US EPA 1998).

Expt 4-survival following passage through oyster digestive tract: Like many other dinoflagellates, Pfiesteria piscicida forms temporary cysts in response to sudden environmental stress (Taylor 1987, Burkholder \& Glagow 1997, Burkholder et al. 2001b). In preliminary experiments we noted that TOX-A and TOX-B zoospores produced temporary cysts after passage through the digestive tract of juvenile and adult Crassostrea virginica. One hundred cysts per replicate $(\mathrm{n}=3)$ from TOX-A and TOX-B treatments were isolated using an hydraulic micromanipulator (Model MMO-202N, Narishige International USA). Cysts were added to $47 \mathrm{~mm}$ glass-bottomed petri dishes containing ultra-filtered natural seawater $(0.22 \mu \mathrm{m}$-porosity Millipore filters) adjusted to a salinity of 15 ppt. Excystment and subsequent zoospore motility were observed at $1 \mathrm{~h}$ intervals for $24 \mathrm{~h}$.

Statistical analyses-Expts 2 to 4. For each experiment, a repeated-measures analysis of variance (ANOVA) model was used to assess the main and interactive effects of treatment and time on the response variable (SAS Institute 1997). The repeatedmeasures factor was time, and the treatments consisted of Pfiesteria piscicida functional type (TOX-A, TOX-B, NON-IND) and/or benign Cryptomonas sp. prey. Response variables were larval survival (Expt 2), grazing rate (Expt 3), and excystment (Expt 4).

\section{RESULTS}

\section{Zoospore predation: directed attack behavior toward larvae}

In Expt 1, Pfiesteria piscicida zoospores (all functional types) showed directed attack behavior toward oyster and scallop larvae. These appeared to be chemosensory and involved a rapid, aggressive feeding response-hence, the term 'attack behavior' (also see Riessen et al. 1985, Tjossem 1990, Lewitus et al. 1999).
At 25 ppt salinity, zoospores swarmed around scallop larvae within seconds (Fig. 1A). After 2 min, zoospores had extended their peduncles and had begun to attach to the outer edge of the larval shell (Fig. 1B). Larvae began to weaken soon thereafter, generally indicated by a noticeable (10 to $15 \mu \mathrm{m})$ valve gape. After 5 to
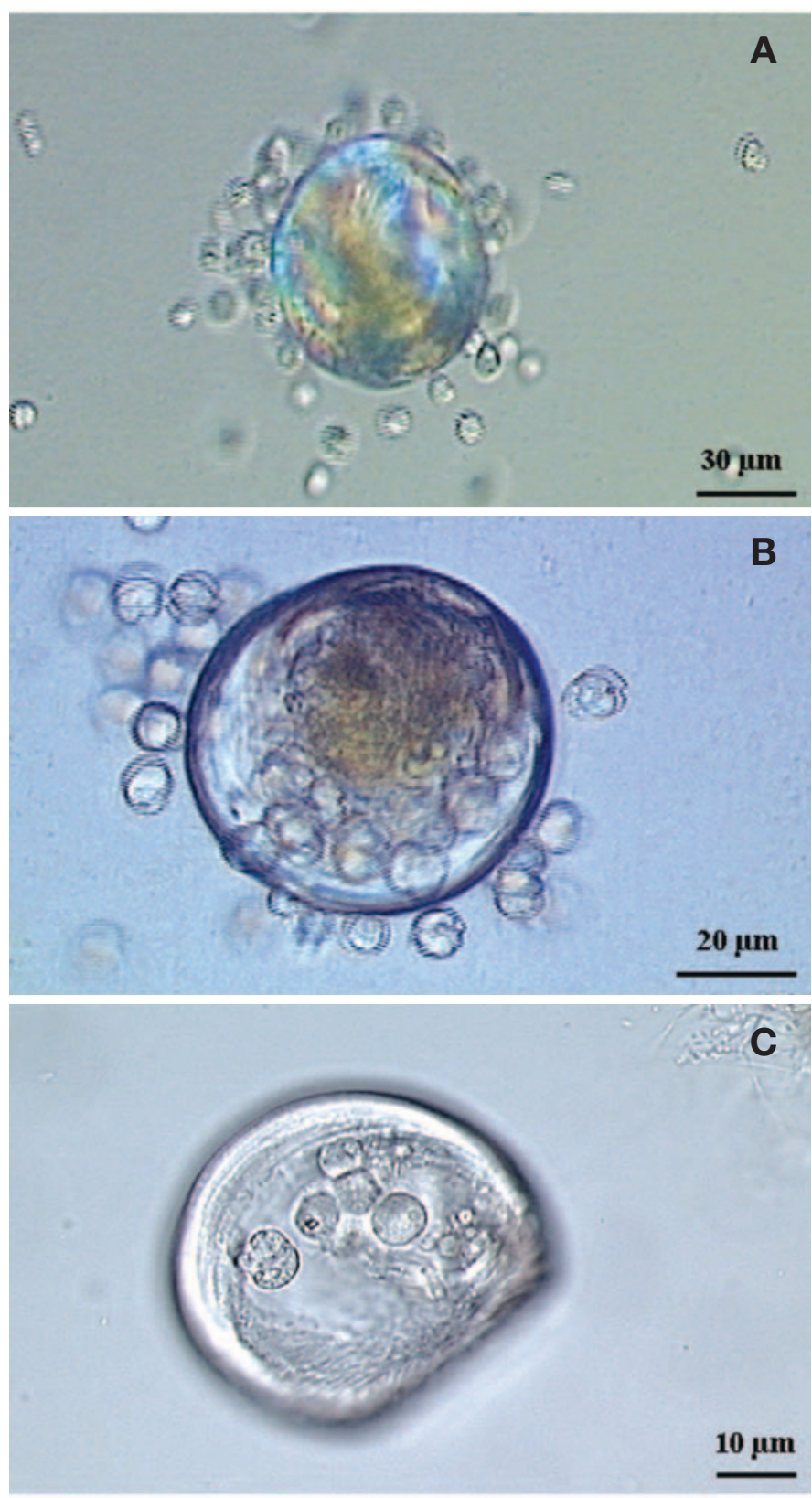

Fig. 1. Pfiesteria piscicida. Actively toxic (TOX-A) zoospores preying upon bay scallop (Argopecten irradians) larvae (salinity $25 \mathrm{ppt}$ ) that had discarded their vela, including (A) zoospores swarming around a larva $(150 \times, t=60 \mathrm{~s})$; (B) zoospores inside the larva consuming its tissues, with some zoospores still swarming outside $(400 \times, t=2 \mathrm{~min})$; and $(\mathrm{C})$ zoospores encysted inside a larva after consuming most soft tissues $(400 \times, t=7 \mathrm{~d})$ 
15 min, most zoospores had penetrated into the larval mantle cavity to consume soft tissues, most notably gill and mantle. The observed zoospore behavior appeared to be more aggressive toward oyster larvae (at 15 ppt) and tempered for bay scallop larvae (at $25 \mathrm{ppt}$ ), although larvae of both species were consumed. An encystment response was noted in satiated (engorged) zoospores ca. $30 \mathrm{~min}$ after introduction. Zoospores that had encysted inside the larvae remained attached to the inside of the shells for up to $1 \mathrm{wk}$ after the conclusion of the experiment (Fig. 1C). It should be noted that only larvae that had discarded their vela were preyed upon by zoospores, whereas larvae with active, extended vela avoided attack. The cilia located on the velar band beat consistently, perhaps acting as an effective deterrent by creating turbulence that prevented zoospore attachment.

\section{Zoospore toxicity to larval shellfish}

In Expt 2, there was $100 \%$ survival of bay scallop larvae in the controls exposed to Cryptomonas sp. held within dialysis tubing. In contrast, significant main effects of Pfiesteria piscicida functional type $(\mathrm{p}<0.0001)$ and time $(\mathrm{p}<0.0001)$ on larval survival were documented when TOX-A and TOX-B zoospores were prevented from direct contact with the scallop larvae (Table 1, Fig. 2). There was also a significant interaction between time and treatment on larval survival ( $p<0.0001)$. Highest and second-highest mortalities were observed for larvae exposed to TOX-A and TOX-B zoospores, respectively, indicating that the TOX-B zoospores had retained residual toxicity toward the larvae. Shellfish mortalities observed in the treatment consisting of 50:50 mix of TOX-A P. piscicida zoospores: Cryptomonas sp. were considered to have resulted from exposure to the toxin from TOX-A zoospores.

\section{Grazing by juvenile and adult oysters on Pfiesteria piscicida}

In Expt 3, no oyster mortality was observed in cryptomonad controls or Pfiesteria treatments throughout the $24 \mathrm{~h}$ period. Clearance of benign cryptomonads from the medium by control juvenile and adult oysters

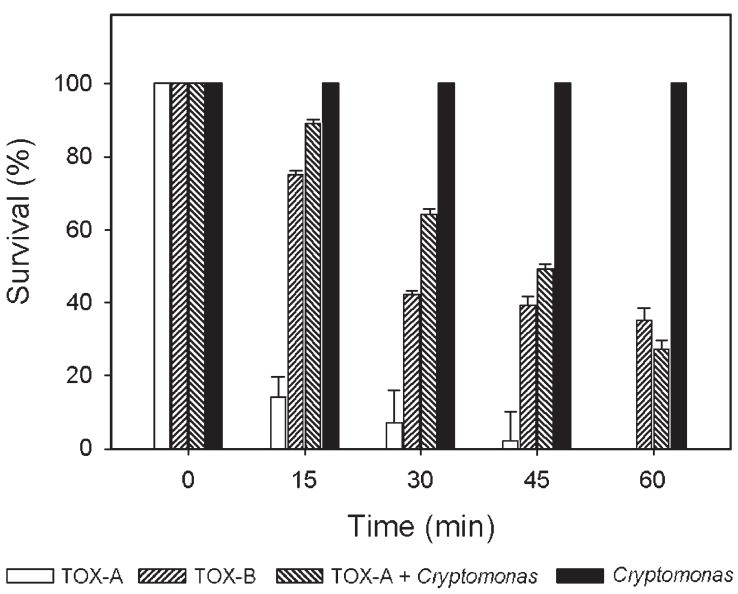

Fig. 2. Argopecten irradians. Survival of larval bay scallops assayed with Pfiesteria piscicida zoospores that were constrained within dialysis tubing to prevent direct contact, including separate trials with actively toxic (TOX-A) zoospores, temporarily nontoxic (TOX-B) zoospores, and a 50:50 mixture of TOX-A zoospores: Cryptomonas sp. (salinity $25 \mathrm{ppt}$; means $\pm 1 \mathrm{SE}, \mathrm{n}=3$ ). Controls were designated as larvae with Cryptomonas sp. cells that were constrained within dialysis tubing 
occurred at a rate similar to clearance of NON-IND $P$. piscicida. However, whereas juvenile oysters rapidly cleared NON-IND $P$. piscicida zoospores from the medium, the TOX-A and TOX-B functional types were cleared at progressively slower rates (e.g. 2050 vs 730 cells $\mathrm{ml}^{-1} \mathrm{~h}^{-1}$ for NON-IND vs TOX-A zoospores, respectively, with intermediate clearing of TOX-B cells: Fig. 3). Pseudofeces production was not observed in any of the experimental trials. There was a significant main effect of treatment $(p=0.0004)$ and time $(p<$ 0.0001 ) on grazing rate, and a significant interactive effect between time and treatment $(p<0.0001$, Table 1$)$.

In contrast, adult oysters rapidly cleared TOX-B and NON-IND Pfiesteria piscicida and the control Cryptomonas sp. from the medium at similar rates (ca. 3000 cells $\mathrm{ml}^{-1} \mathrm{~h}^{-1}$ ), whereas clearance of TOX-A zoospores was significantly slower (ca. 1700 cells ml $^{-1}$ $\mathrm{h}^{-1}$; Fig. 4). There was a significant main effect of treatment $(p=0.0018)$ and time $(p<0.0001)$ on grazing rate as well as a significant interactive effect between time and treatment $(\mathrm{p}<0.0001$, Table 1$)$.

\section{Excystment of toxic Pfiesteria picicida following gut passage}

In Expt 4, qualitative analysis of fecal material from adult oysters $1 \mathrm{~h}$ after exposure to Pfiesteria piscicida indicated that TOX-A and TOX-B zoospores had been packaged into the fecal ribbon (Fig. 5). Many of the ingested zoospores formed temporary cysts as they passed through the oyster digestive tract. These cells rapidly excysted; $50 \%$ had regained motility within $6 \mathrm{~h}$,

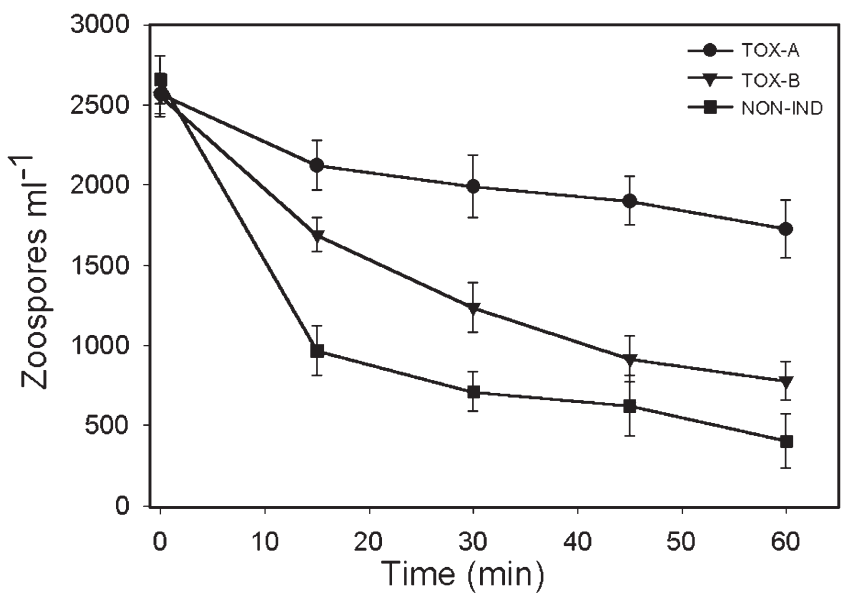

Fig. 3. Crassostrea virginica. Grazing of juvenile eastern oysters on Pfiesteria piscicida zoospores, including actively toxic (TOX-A), temporarily nontoxic (TOX-B), and non-inducible (NON-IND) functional types (salinity $15 \mathrm{ppt}$ means $\pm 1 \mathrm{SE}$, $\mathrm{n}=3$ ). Grazing on cryptomonads (data not shown) was comparable to that on NON-IND zoospores

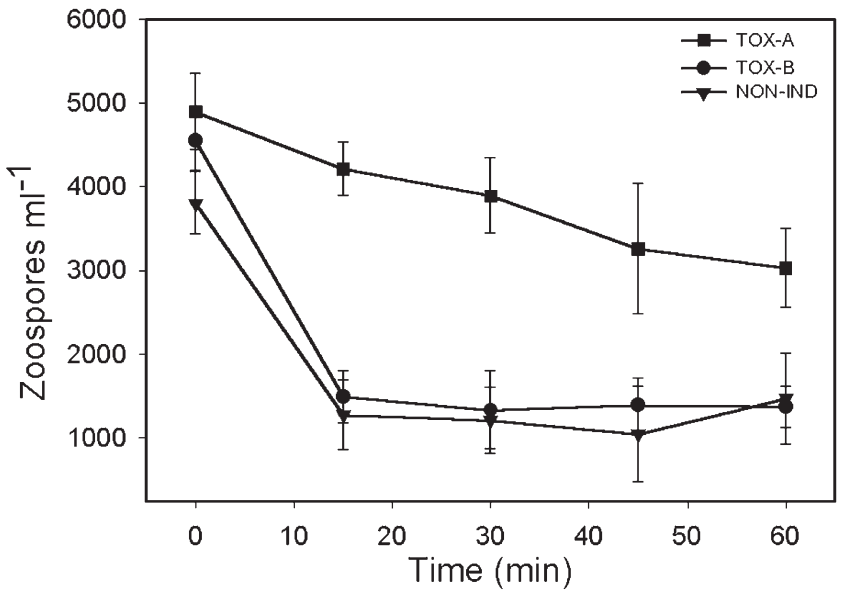

Fig. 4. Crassostrea virginica. Grazing of adult eastern oysters on Pfiesteria piscicida zoospores, including actively toxic (TOX-A), temporarily nontoxic (TOX-B), and non-inducible

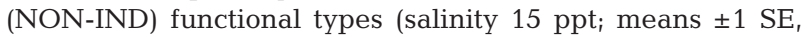
$\mathrm{n}=3$ ). Grazing on cryptomonads (data not shown) was comparable to that on TOX-B and NON-IND zoospores

and $>75 \%$ had regained motility within $24 \mathrm{~h}$ (Fig. 6). The remaining temporary cysts did not produce motile zoospores over $5 \mathrm{~d}$ of additional observation. There were significant main effects of treatment $(p=0.0134)$ and time $(\mathrm{p}<0.0001)$ on excystment, and a significant interactive effect between time and treatment $(\mathrm{p}<$ $0.0001 ;$ Table 1)

\section{DISCUSSION}

This study has documented, for the first time, direct feeding behavior of the toxic dinoflagellate Pfiesteria piscicida on shellfish larvae. For these tested strains, both TOX-A and TOX-B zoospores aggressively began to consume bay scallop and eastern oyster larvae within seconds. Such behavior has not been published, to our knowledge, for other toxic dinoflagellate species, and subsequent encystment within the pediveliger shells may provide protection from watercolumn microfaunal predators known to consume $P$. piscicida (Stoecker et al. 2002).

In addition to the larval mortality from zoospore feeding, we also demonstrated a toxic effect of Pfiesteria piscicida zoospores on bay scallop larvae. In previous research conducted with $P$. piscicida and adult bay scallops, $100 \%$ mortality of adult bay scallops was observed $<20 \mathrm{~min}$ after the shellfish had been added to actively toxic $P$. piscicida cultures with live finfish (Burkholder et al. 1992, Burkholder \& Glasgow 1997). Pfiesteria spp. behavior has been shown to differ substantially among strains, including strains within the same functional type (Burkholder et al. 2001a). Thus, 


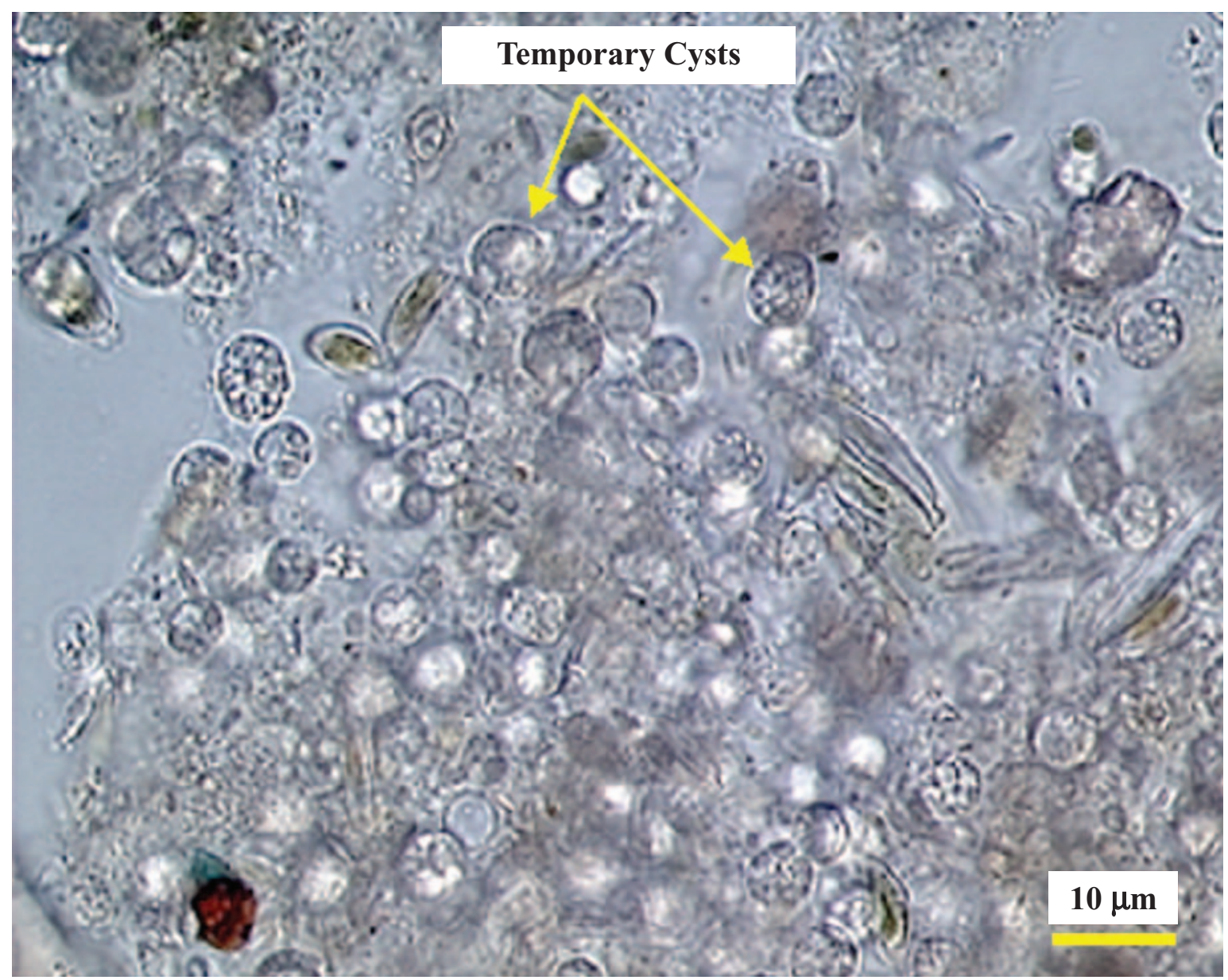

Fig. 5. Pfiesteria piscicida. Fecal strand containing TOX-A zoospores that had formed temporary cysts after passage through the digestive tract of an adult eastern oyster (Crassostrea virginica) $(400 \times$, salinity $15 \mathrm{ppt}, t=24 \mathrm{~h})$

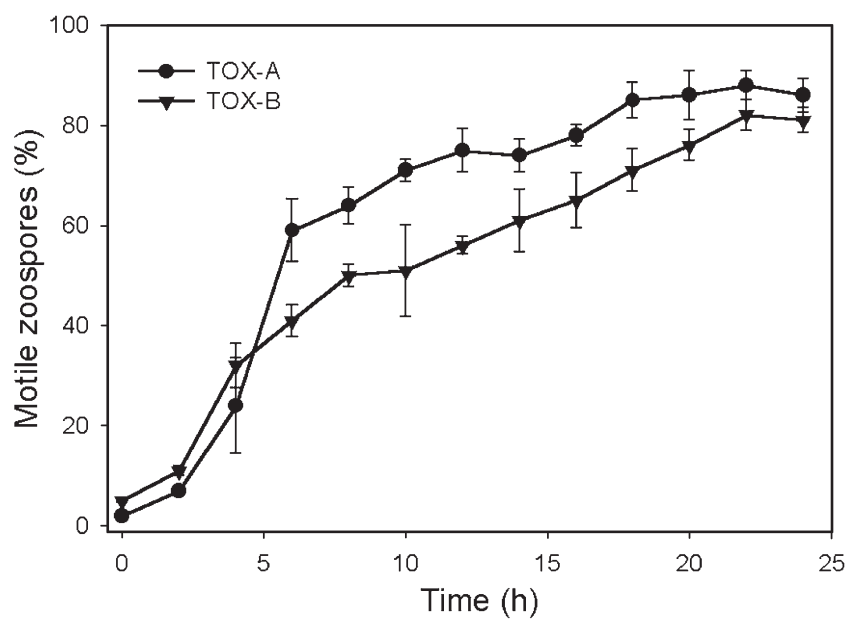

Fig. 6. Pfiesteria piscicida. Excystment of zoospores after passage through the digestive tract of adult eastern oysters (salinity $15 \mathrm{ppt}_{\text {; }}$ means $\pm 1 \mathrm{SE}, \mathrm{n}=3$ ) some Pfiesteria toxic strains have been lethal to finfish when held within dialysis membranes to prevent direct contact, as in this study with shellfish, whereas others have required close proximity or direct contact for lethal effects (Burkholder et al. 2001b). We expect that such variability in impacts among Pfiesteria strains, which may be related to production of different toxin(s) as in other dinoflagellates (Hallegraeff et al. 1995), also extends to shellfish.

The behavior and feeding trials of this study indicate that Pfiesteria piscicida zoospores could potentially affect shellfish recruitment and survival. Larval and juvenile oysters were sensitive even to residual toxicity from TOX-B zoospores that had been without live fish for an extended period (weeks). In contrast, adult oysters responded similarly to TOX-B and NON-IND zoospores, and appeared to be insensitive to residual toxicity of TOX-B zoospores. Adult oysters actively 
grazed bloom concentrations of $P$. piscicida zoospores $\left(5 \times 10^{3}\right.$ cells ml ${ }^{-1}$; cell densities during toxic outbreaks are $>3 \times 10^{2}$ to $10^{4}$ cells ml $^{-1}$; Burkholder \& Glasgow 1997, Burkholder et al. 2001a). Burkholder et al. (1995) did not observe adult oyster mortality after 3 wk from feeding toxic Pfiesteria spp. continuously at similar densities $\left(2 \times 10^{3}\right.$ TOX-A cells ml $\left.{ }^{-1}\right)$.

To assess the relevance of these laboratory results, the data should be considered within the context of the potential for overlap of actively and potentially toxic Pfiesteria piscicida with the habitat and recruitment periods for bay scallops and eastern oysters. The major period of activity by TOX-A and TOX-B zoospores ranges from March through October (occasionally through December; Burkholder et al. 1995). TOX-B zoospores (algivorous/omnivorous) appear to track the spring phytoplankton bloom in North Carolina estuaries (research in the Neuse Estuary; Burkholder et al. 2001a, Glasgow et al. 2001a), reaching maximal densities in April. TOX-A zoospores (piscivorous) are maximal in late summer to early fall, as Atlantic menhaden (Brevoortia tyrannus Latrobe) begin to move downestuary for fall migration out to sea (Manooch 1988, Glasgow et al. 2001a). Argopecten irradians has a relatively narrow salinity range and prefers waters ranging from 20 to $30 \mathrm{ppt}$ (Tettelbach \& Rhodes 1981), while Crassostrea virginica occurs across a fairly broad salinity range from ca. 3 to $31 \mathrm{ppt}$ (Carriker 1951). P. piscicida is capable of lethal activity toward fish across a salinity range from ca. 2 to 35 ppt (Burkholder et al. 1995, 2001a), with an optimum of ca. 15 ppt in North Carolina waters. A. irradians generally spawns during the late summer months, but can spawn from May through October depending on the latitude and the sub-population (Rhodes 1990). Populations of C. virginica on the Gulf Coast and north along the Atlantic Coast to Virginia tend to produce a major spawn in the spring, with minor spawning throughout the summer followed by another major spawn in the fall (Hayes \& Menzel 1981, Ortega \& Sutherland 1992, Thompson et al. 1996). Therefore, a portion of the spawning cycle of both species overlaps the period of zoospore activity in toxic $P$. piscicida strains. The available evidence suggests that $P$. piscicida could potentially impact both shellfish species in their natural habitat, with a higher likelihood of affecting $C$. virginica.

These data indicate the potential for adult Crassostrea virginica to concentrate toxic Pfiesteria piscicida cells and, thus, $P$. piscicida toxin through filter-feeding activity. The extent to which this may occur cannot be determined until purified toxin standard becomes available for development of a reliable assay to detect the toxin in shellfish. Such an assay would also facilitate study of chronic, long-term impacts from exposure to toxic Pfiesteria strains on major life-history stages of these and other shellfish species in habitats of cooccurrence. This study also showed high survival of toxic $P$. piscicida following passage through the digestive tract of adult $C$. virginica as temporary cysts. Thus, there is a high likelihood that viable Pfiesteria toxic strains could be transported from one geographic region to another via movement of shellfish broodstock and relaying activities (see Shumway 1990, Hallegraeff 1993).

In summary, we have demonstrated the potential for planktonic (larval) bay scallops and eastern oysters to be affected adversely by an aggressive feeding response of Pfiesteria piscicida zoospores toward soft tissues, and also by toxin from P. piscicida. Grazing rates of Crassostrea virginica on P. piscicida zoospores were dependent on the $P$. piscicida functional type. Of particular importance to natural resource managers is the finding that TOX-A and TOX-B zoospores survived passage through the digestive tract of adult $C$. virginica. Thus, activities of aquaculture operations may inadvertently contribute to the transfer of viable $P$. piscicida cysts between geographic locations. Although $P$. piscicida blooms have been linked to certain major finfish kills in mid-Atlantic US coastal estuaries (Glasgow et al. 2001a), historically little attention has been directed toward the health of shellfish populations in the affected areas. We recommend that field-based monitoring and research activities should include resident shellfish populations to gain further insights about shellfish health in estuarine waters inhabited by toxic Pfiesteria species.

\section{LITERATURE CITED}

Allen IC Jr (2000) Utilization of PCR and FISH to determine fine scale and global distribution of Pfiesteria species. MS thesis, Department of Biology, UNC-Greensboro, Greensboro, NC

Anderson DM (1991) Toxin variability in Alexandrium. In: Granéli E, Sundstrom B, Edler L, Anderson DM (eds) Toxic marine phytoplankton. Proceedings of the Fourth International Conference on Toxic Marine Phytoplankton. Elsevier, New York, p 41-51

Bates SS, Garrison DL, Horner RA (1998) Bloom dynamics and physiology of domoic acid-producing Pseudonitzschia species. In: Anderson DM, Cembella A, Hallegraeff GM (eds) Physiological ecology of harmful algae. NATO ASI Series G: Ecological sciences, Vol 41. Springer-Verlag, Berlin, p 267-292

Bricelj VM, Shumway SE (1998) Paralytic shellfish toxins in bivalve molluscs: occurrence, transfer kinetics, and biotransformation. Rev Fish Sci 6:315-383

Burkholder JM (1998) Implications of harmful microalgae and heterotrophic dinoflagellates in management of sustainable marine fisheries. Ecol Appl 8(Suppl):S37-S62

Burkholder JM, Glasgow HB (1995) Interactions of a toxic estuarine dinoflagellate with microbial predators and prey. Arch Protistenkd 145:177-188

Burkholder JM, Glasgow HB (1997) Pfiesteria piscicida and 
other Pfiesteria-like dinoflagellates: behavior, impacts, and environmental controls. Limnol Oceanogr 42:1052-1075

Burkholder JM, Glasgow HB (2001) History of toxic Pfiesteria in North Carolina estuaries from 1991 to the present. BioScience 51:827-841

Burkholder JM, Noga EJ, Hobbs CW, Glasgow HB, Smith SA (1992) New 'phantom' dinoflagellate is the causative agent of major estuarine fish kills. Nature 358:407-410

Burkholder JM, Glasgow HB, Hobbs CW (1995) Fish kills linked to a toxic ambush-predator dinoflagellate: distribution and environmental conditions. Mar Ecol Prog Ser 124: 43-61

Burkholder JM, Mallin MA, Glasgow HB (1999) Fish kills, bottom-water hypoxia, and the toxic Pfiesteria complex in the Neuse River and Estuary. Mar Ecol Prog Ser 124:43-61

Burkholder JM, Glasgow HB, Deamer-Melia NJ (2001a) Overview and present status of the toxic Pfiesteria complex. Phycologia 40:106-134

Burkholder JM, Glasgow HB, Deamer-Melia NJ, Springer J, Parrow MW, Zheng C, Cancellieri P (2001b) Species of the toxic Pfiesteria complex, and the importance of functional type in data interpretations. Environ Health Perspect 109 (Suppl 5):667-679

Burkholder JM, Marshall HG, Seaborn DW, Glasgow HB (2001c) The standardized fish bioassay procedure for detecting and culturing actively toxic Pfiesteria, used by two reference laboratories for Atlantic and Gulf Coast states. Environ Health Perspect 109(Suppl 5):745-756

Cancellieri P, Burkholder JM, Deamer-Melia NJ, Glasgow HB (2001) Chemosensory attraction of zoospores of the estuarine dinoflagellates, Pfiesteria piscicida, P. shumwayae, and a cryptoperidiniopsoid to finfish mucus and excreta. J Exp Mar Biol Ecol 264:29-45

Carriker MR (1951) Ecological observations on the distribution of oyster larvae in New Jersey estuaries. Ecol Monogr 21:19-38

Edvardsen B, Paasche E (1998) Bloom dynamics and physiology of Prymnesium and Chrysochromulina. In: Anderson DM, Cembella A, Hallegraeff GM (eds) Physiological ecology of harmful algae. NATO ASI Series G: Ecological sciences, Vol 41. Springer-Verlag, Berlin, p 193-208

Gainey LF, Shumway SE (1988a) A compendium of the responses of bivalve mollusks to toxic dinoflagellates. J Shellfish Res 7:623-628

Gainey LF, Shumway SE (1988b) Physiological effects of Protogonyaulax tamarensis on cardiac activity in bivalve molluscs. Comp Biochem Physiol 91:159-164

Gentien P, Arzul G (1990) Exotoxin production by Gyrodinium cf. aureolum (Dinophyceae). J Mar Biol Assoc UK 70:571-581

Glasgow HB, Burkholder JM (2000) Water quality trends and management implications from a five-year study of a eutrophic estuary. Ecol Appl 10:1024-1046

Glasgow HB, Burkholder JM, Mallin MA, Deamer-Melia NJ, Reed RE (2001a) Field ecology of toxic Pfiesteria complex species and a conservative analysis of their role in estuarine fish kills. Environ Health Perspect 109(Suppl 5):715-730

Glasgow HB, Burkholder JM, Morton SL, Springer J (2001b) A second species of toxic Pfiesteria. Phycologia 40:234-245

Guillard RRL (1975) Culture of phytoplankton for feeding marine invertebrates. In: Smith WL, Chanley $\mathrm{MH}$ (eds) Culture of marine invertebrate animals. Plenum Press, New York, p 29-60

Hallegraeff GM (1993) A review of harmful algae and their apparent global increase. Phycologia 32:79-99

Hallegraeff GM, Anderson DM, Cembella AD (1995) Manual on harmful marine microalgae. Intergovernmental Oceano- graphic Commission manuals and guides No. 33. United Nations Educational, Scientific and Cultural Organization (UNESCO), Paris

Hayes PF, Menzel RW (1981) The reproductive cycle of early setting Crassostrea virginica (Gmelin) in the northern Gulf of Mexico, and its implications for population recruitment. Biol Bull 160:80-88

Jakobsen KS, Tengs T, Vatne A, Bowers HA and 5 others (2002) Discovery of the toxic dinoflagellate, Pfiesteria, from northern European waters. Proc R Soc Lond Ser B Biol Sci 269:211-214

Kimm-Brinson KL, Moeller PDR, Barbier M, Glasgow HB, Burkholder JM, Ramsdell JS (2001) Identification of a $\mathrm{P}_{2} \mathrm{X}_{7}$ receptor in GH4C1 rat pituitary cells: a target for a bioactive substance produced by Pfiesteria piscicida. Environ Health Perspect 109:457-462

Lewitus AJ, Rublee PA, Mallin MA, Shumway SE (1999) Human health and environmental impacts from Pfiesteria: a science-based rebuttal to Griffith. Hum Organ 58:455-458

Lund JWG, Kipling C, LeCren ED (1958) The inverted microscope method of estimating algal numbers and the statistical basis of estimates by counting. Hydrobiologia 11: $143-170$

Magnien RE (2001) The dynamics of science, perception, and policy during the outbreak of Pfiesteria in the Chesapeake Bay. BioScience 51:843-852

Magnien RE, Goshorn D, Michael B, Tango P, Karrh R (2000) Associations between Pfiesteria, fish health, and environmental conditions in Maryland. Final Report. Tidewater Ecosystem Assessment, Maryland Department of Natural Resources, Annapolis

Manooch CS III (1988) Fisherman's guide-fishes of the southeastern United States. North Carolina Museum of Natural History, Raleigh

Marshall HM, Gordon AS, Seaborn DW, Dyer B, Dunstan WM, Seaborn A (2000) Comparative culture and toxicity studies between the toxic dinoflagellate, Pfiesteria piscicida and a morphologically similar cryptoperidiniopsoid dinoflagellate. J Exp Mar Biol Ecol 255:65-74

Matsuyama Y, Uchida T, Honjo T (1999) Effects of harmful dinoflagellates, Gymnodinium mikimotoi and Heterocapsa circularisquama, red-tide on filtering rate of bivalve molluscs. Fish Sci (Tokyo) 65:248-253

Melo AC, Moeller PDR, Glasgow HB, Burkholder JM, Ramsdell JS (2001) Microfluorimetric analysis of a purinergic receptor $\left(\mathrm{P}_{2} \mathrm{X}_{7}\right)$ in $\mathrm{GH}_{4} \mathrm{C}_{1}$ rat pituitary cells: effects of a bioactive substance produced by Pfiesteria piscicida. Environ Health Perspect 109(Suppl 5):731-738

Oldach DW, Delwiche CF, Jakobsen KS, Tengs T and 8 others (2000) Heteroduplex mobility assay guided sequence discovery: elucidation of the small subunit (18S) rDNA sequence of Pfiesteria piscicida from complex algal culture and environmental sample DNA pools. Proc Natl Acad Sci USA 97:4304-4308

Ortega S, Sutherland JP (1992) Recruitment and growth of the eastern oyster, Crassostrea virginica, in North Carolina. Estuaries 15:158-170

Parrow MW, Glasgow HB, Burkholder JM, Zhang C (2002) Comparative response to algal prey by Pfiesteria piscicida, Pfiesteria shumwayae, and a co-occurring 'lookalike' species. In: Hallegraeff GM, Blackburn SI, Bolch CJ, Lewis R (eds) Proceedings of the Ninth International Conference on Harmful Algal Blooms. UNESCO, Paris, p 101-104

PICWG (Pfiesteria Interagency Coordination Working Group) (2002) Glossary of Pfiesteria-related terms. US EPA, (United States Environmental Protection Agency) Baltimore, p 1-9 
Rhodes E (1990) Fisheries and Aquaculture of the bay scallop, Argopecten irradians, in the eastern United States. In: Shumway SE (ed) Scallops: biology, ecology, and aquaculture. Developments in aquaculture and fisheries science, Vol 21. Elsevier, New York, p 913-924

Rhodes L, Burkholder JM, Glasgow HB, Rublee PA, Allen C, Adamson JE (2002) Pfiesteria shumwayae in New Zealand. NZ J Mar Freshw Res 36:621-630

Riessen H, O'Brien WJ, Loveless B (1985) An analysis of the components of Chaoborus predation on zooplankton and the calculation of relative prey vulnerabilities. Ecology 65:514-522

Rublee PA, Kempton J, Schaefer E, Burkholder JM, Glasgow HB, Oldach DW (1999) PCR and FISH detection extends the range of Pfiesteria piscicida in estuarine waters. Va J Sci 50: 325-335

Rublee PA, Kempton JW, Schaefer EF, Allen C and 6 others (2001) Use of molecular probes to assess geographic distribution of Pfiesteria species. Environ Health Perspect 109 (Suppl 5):765-767

SAS Institute (1997) SAS/STAT guide for personal computers, Version 8.01. SAS Institute, Cary, NC

Shumway SE (1990) A review of the effects of algal blooms on shellfish and aquaculture. J World Aquacult Soc 21:65-104

Shumway SE (1995) Phycotoxin-related shellfish poisoning: bivalve molluscs are not the only vectors. Rev Fish Sci 3:1-31

Shumway SE, Cucci T (1987) The effects of the toxic dinoflagellate, Protogonyaulax tamarensis, on the feeding and behavior of bivalve molluscs. Aquat Toxicol (NY) 10:9-27

Shumway SE, Cucci TL, Gainey L, Yentsch CM (1985) A preliminary study of the effects of Gonyaulax tamarensis on feeding in bivalve molluscs. In: Anderson DM, White AW, Baden DG (eds) Toxic phytoplankton blooms in the sea. Proceedings of the 3rd International Conference on Toxic

Editorial responsibility: John Lawrence (Contributing Editor), Tampa, Florida, USA
Dinoflagellates, St. Andrews, New Brunswick (Canada). Elsevier, New York, p 389-394

Shumway SE, Selvin R, Schick DF (1987) Food resources related to habitat in the scallop Placopecten magellanicus (Gmelin, 1791): a qualitative study. J Shellfish Res 6:89-96

Skulberg OM, Carmichael WW, Codd GA, Skulbeg R (1993) Taxonomy of toxic Cyanophyceae (cyanobacteria). In: Falconer IR (ed) Algal toxins in seafood and drinking water. Academic Press, New York, p 1-28

Stoecker DK, Parrow MW, Burkholer JM, Glasgow HB (2002) Grazing by microzooplankton on Pfiesteria piscicida cultures with different histories of toxicity. Aquat Microb Ecol 28:79-85

Taylor FJR (1987) Dinoflagellate morphology. In: Taylor FJR (ed) The biology of dinoflagellates. Bot Monogr 21. Blackwell, Boston, p 2-91

Tettelbach ST, Rhodes EW (1981) Combined effects of temperature and salinity on embryos and larvae of the northern bay scallop, Argopecten irradians irradians. Mar Biol 63:249-256

Thompson RJ, Newell RIE, Kennedy VS, Mann R (1996) Reproductive processes and early development. In: Kennedy VS, Newell RIE, Elbe AF (eds) The eastern oyster, Crassostrea virginica. Maryland Sea Grant, College Park, p 335-370

Tjossem S (1990) Effects of fish chemical cues on vertical migration behavior of Chaoborus. Limnol Oceanogr 35: 1456-1468

US EPA (US Environmental Protection Agency) (1998) Quality assurance management plan for EPA Region 4. Document Control Number R4QAM-97001, Revision 1, May. US EPA, Region 4, Atlanta, GA

Vollenweider RA, Munawar M, Stadelmann P (1974) A comparative review of phytoplankton and primary production in the Laurentian Great Lakes. J Fish Res Board Can 31: $739-762$

Submitted: September 7, 2001; Accepted: June 18, 2002

Proofs received from author(s): December 2, 2002 